\title{
Economic structure and agricultural productivity in Europe, $1300-1800$
}

\author{
ROBERT C. ALLEN \\ Department of Economics, University of British Columbia, Vancouver, BC, \\ V6T I $Z_{I}$, Canada
}

\begin{abstract}
Estimates of employment structure, agricultural output, and agricultural labour productivity are developed for the leading European countries from I300 to I800. The employment estimates are developed from estimates of the total, urban, and rural populations. The output estimates are derived by positing a demand curve for agricultural goods.
\end{abstract}

Rising agricultural productivity is central to economic development and has been studied by the historians of many countries. Much has been learned about their separate histories, but long-term, cross-national comparisons remain elusive. Crop yields have received considerable attention, ${ }^{\mathrm{I}}$ and progress has been made in understanding their evolution. However, labour productivity is arguably a more important variable in explaining the transition to an urban, industrial economy, and our knowledge of its history is weak indeed. Bairoch (1965, p. I096) has provided some useful comparisons across countries for the nineteenth century, but the lack of censuses for earlier years has frustrated attempts to measure the growth in labour productivity before the industrial revolution.

A well known paper by Wrigley (1985) is an influential attempt to measure labour productivity growth before the nineteenth century. ${ }^{2}$ The method is an outgrowth of demographic reconstruction. Population historians have established reasonable estimates of the populations of many European countries during the early modern period as well as fairly sound estimates of their urban populations. The difference is, of course, the rural population. Wrigley assumed that this could be divided into an agricultural

' Slicher van Bath (1963) is the most extensive. Other comparative studies include van Bavel and Thoen (n.d.), Allen and Ó Gráda (1988), Chorley (I98I), O’Brien and Keyder (I978).

2 Clark (1987, 1989, 1991) has attempted to infer labour productivity from piece rates. The procedure has been challenged by Komlos (1988). Persson (1988, I991, I993) has also proposed a method for measuring labour productivity in early modern agriculture that has considerable affinity to the procedures used here. Both Persson's method and mine make the consumption of agricultural goods a function of income and use data on trade and urbanisation to infer farm labour productivity. 
and a nonagricultural portion (his method will be considered later). $\mathrm{He}$ broke down the populations of England, France, and the Netherlands into urban, rural agricultural, and rural nonagricultural for the period I 500-I800. Finally, Wrigley measured agricultural labour productivity as the ratio of the total population to the agricultural population. He found that output per worker was similar in England and France in 1500, that it increased in the next three centuries in both countries, and that the rate of growth was higher in England than in France, so England had a pronounced lead in agricultural labour productivity by 1800 .

Wrigley's method requires strong assumptions of which he was aware. If there were no international trade in agricultural products - so domestic consumption equals domestic production - and if consumption per capita of agriculture goods were a constant across time and over space, then agricultural production would be proportional to the total population. In that case, dividing the total population by the agricultural population measures output per worker in agriculture. For later development, it is useful to express the calculation algebraically. If $A$ equals the agricultural population, $N$ the total population, $Q$ total agricultural output, $r$ the ratio of agricultural production to agricultural consumption (and thus an indicator of the balance of international trade in agricultural goods), and $c$ consumption per capita of agricultural goods, then output per worker in agriculture equals:

$$
\frac{\mathrm{Q}}{\mathrm{A}}=\frac{\mathrm{rcN}}{\mathrm{A}}
$$

The rub is that $r$ and $c$ were not constants. The problems are comparatively minor for $r$. The simplest assumption is that it equalled I (consumption equalled production, i.e. no trade in agricultural goods), and most calculations place it within ten per cent of that value. The error that arises from assuming that $r$ equals one is small compared to the changes and differences in labour productivity reported here.

The greater difficulty is the assumed constancy of $c$. This has been a widely debated and carefully researched issue in English agricultural history. There was a long tradition of assuming that food consumption per head was constant in England - one quarter of bread grain per person per year was a standard formulation - and leaping from that to an extrapolation of agricultural output from population estimates. Deane and Cole (I969, pp. 62-75) adopted such a procedure in their estimates of economic growth in the eighteenth century, and (remarkably in view of the subsequent discussion) Overton (1996a, pp. 3-7, 1996b, p. 75) has continued the tradition. However, Crafts (1976) long ago pointed out that the assumed constancy of per capita agricultural commodities made sense only if the income and price elasticity of demand for farm goods were zero. Many econometric studies of developing countries have shown that these assumptions are not true, as have investigations of eighteenth and nineteenth century British data (Clark 
et al. 1995, pp. 221-5). The estimation of agricultural output growth must recognise the variability of per capita consumption. Crafts (1976) proposed one method for doing it, and others, particularly Jackson (1985) and Allen (1999), have proposed variants. These procedures all imply very different histories for output growth in the eighteenth century than simple extrapolations from population figures.

This article combines the best features of the various methods used to date to measure structural change and output per worker in agriculture. I follow Wrigley's lead in charting changes in the structure of the economy by dividing the population into urban, rural nonagricultural, and agricultural components. The latter is the denominator in measuring output per worker in agriculture by equation I. While following Wrigley this far, I part company with him in estimating the numerator (agricultural output). Instead of assuming that $r$ always equalled one and $c$ was constant, I develop estimates of $r$ for the most likely cases where it differed from one and treat $c$ as a function of price and income. While all stages of the calculation are problematic to some degree, the results are surprisingly plausible and show the implications of applying a simple analytic framework to European history.

The estimates of employment and labour productivity are easier to interpret if they are considered in the light of changes in living standards in the period. Real wages were quite similar across Europe in I500; they diverged substantially in the next three centuries. On most of the continent, real wages dropped by 50 per cent or more; in Eng!and, Belgium, and the Netherlands, they either rose or declined only slightly (Allen 1998). Northwestern Europe was also the region in which population grew the most rapidly, so the preservation of high wages is all the more remarkable and highlights the significance of the economic development taking place there. The question is whether that development is mirrored in the occupational structure or agricultural labour productivity.

Indeed, the changes in wages and economic structure were closely related. This is clear if the countries are divided into four groups.

The first consists of England alone. It was a backward, agrarian, low productivity, low wage economy in the late Middle Ages, but after 1600 it became the most successful economy in Europe. In the seventeenth and eighteenth centuries, it had the most dramatic structural change with rapidly growing urban and protoindustrial populations, the most rapid growth of agricultural productivity, and generally rising real wages despite the most rapidly growing population in Europe.

The second group consists of Belgium and the Netherlands. In the late medieval period, Belgium was the most urbanised part of Europe and had the most productive agriculture. While settlement was light in the Netherlands at that time, the Dutch Republic was similar in many respects to Belgium from I500 (when the Dutch data begin) onward. Wages were 
always high in this region and especially in the Middle Ages. Thereafter, wages declined moderately but remained much higher than in the less successful economies. Agricultural productivity was high in the eighteenth century, and the agricultural sector relatively small. Next to England, these were the most successful European economies of the period.

The third group consists of Italy and Spain. Like the Low Countries, they were the other developed parts of Europe in the late Middle Ages. Agriculture's share of employment was relatively low, while urbanisation and wages were high. Unlike Belgium, however, agricultural productivity in Italy and Spain was no higher than elsewhere. In the early modern period, there was very little structural change in these economies and even the moderate population growth that occurred led to a collapse in wages. Italy and Spain were remarkable in dropping from among the most successful to the least successful economies in Europe.

The fourth group consists of France, Germany, Poland, and the combination of Austria, Hungary, and Czechoslovakia. They were predominantly agrarian economies in the Middle Ages with only small urban sectors. Agricultural productivity was not exceptional. During the early modern period, there was some growth of rural manufacturing at the expense of agricultural employment but otherwise little structural change. Agricultural productivity sank in these countries in response to population growth, although there was some suggestion of advance in France and perhaps in Poland in the early eighteenth century. Wages declined in these countries. They were neither successful economies in the Middle Ages nor in the eighteenth century.

\section{The structure of the labour force and the agricultural population}

I develop estimates of the agricultural labour force by applying Wrigley's procedure to the principal countries of Europe. The method is to pare the total population down to the agricultural population by splitting off segments containing no cultivators. The obvious first step is deducting the urban population on the assumption that city dwellers were not farmers. This assumption is substantially - but not perfectly - true, as De Vries' and van der Woude's (1997, p. 526) reconstruction of the Dutch population c. I 800 shows. They found that 6 per cent of the urbanites were agriculturalists, who, in turn, accounted for 5 per cent of the Netherland's farm labour force. Clearly, some people lived in small cities and cultivated the surrounding fields or grazed stock on meadows and commons. There is no easy way to estimate the number of urban farmers, but their number was small as is the error from assuming it was zero.

Generally I have used Bairoch's (1976, p. 312, 1988a, pp. 259, 297) figures for the total and urban populations and computed the rural population 
as the difference. While Bairoch reports figures for the United Kingdom (Great Britain and Ireland), I have, instead, used figures for England and Wales in order to facilitate comparison with previous work on English agriculture. All of Bairoch's population figures ostensibly apply to the territories delimited by post-World War II boundaries. Clearly some of these population figures are more reliable than others: the English population in 1500 is known with more accuracy than is the Polish population at the same date.

The definition of a city is an important conceptual issue in this exercise. I follow Bairoch's lead in defining cities to be settlements with populations of 5,000 or more. Other definitions have been used in the literature. De Vries' (I984) recent work sets the threshold at I0,000; sometimes 2,000 is chosen. Occasionally administrative or economic criteria are used instead of population. Clearly, the urban population will be greater if the lower bound is set at 2,000 rather than at 10,000 . Consistency of definition is important, but more substantial issues are also at stake. One is the extent of protoindustry or rural manufacturing. The lower the population threshold defining a city, the smaller will be the fraction of the rural population engaged in manufacturing. A manufacturing settlement of 3,500 people will be defined as urban when the threshold is 2,000 but as rural when the threshold is 5,000 . How much rural industry we find depends on how we define the city. Conversely, the urban population will contain more farmers when the threshold is set at 5,000 than when I0,000 is chosen.

The second step is to split the rural population into agricultural and nonagricultural populations. The attempt is vulnerable to the objection that many people worked in both economies. A farmer, for instance, who carted grain for a neighbour was engaged in the 'transportation' industry (nonagricultural) as well as agriculture. The practical import of this observation is that some of the time of people classified as agricultural should probably be assigned to the nonagricultural sector. So long as this fraction is constant, however, no error is introduced into the labour productivity calculations.

While there was fuzziness along the edges, most people were predominantly agriculturalists or nonagriculturalists. The latter included domestic servants, transporters, building craftsmen, bakers, millers, innkeepers, shoemakers, tailors, clergymen, shopkeepers, and so forth (De Vries and Van der Woude 1997, pp. 516-17). Such people were probably present at all times. In addition, starting in the sixteenth century, there were the rural manufacturers or protoindustrialists. In many countries, export oriented manufacturing spread from the cities to the countryside in this period. In some regions where the farming potential was limited, mining or manufacturing became the predominant activity, while manufacturing became widespread even in prime agricultural areas. ${ }^{3}$

${ }^{3}$ See Allen (1992, pp. 252-7) for a discussion of this in Northamptonshire and Leicestershire. 
How many people were employed outside agriculture? Direct evidence is available only c. I800, which is important since it marks the end of the preindustrial period considered in this article. We possess such estimates for England and Wales, ${ }^{4}$ Germany, France, Spain, and the Netherlands. For other countries, estimates must be constructed from later census figures using the occupational distribution of the population. For most countries there were mid-nineteenth century censuses, although for Poland the earliest figures come from the Russian census of I897. Table I summarises the available information in terms of the fraction of the total population that was agricultural, the fraction that was urban, and the ratio of the first to the second, which equals the fraction of the rural population engaged in agriculture. England recorded the lowest proportion of the rural population in agriculture (5I per cent in I800), while Spain recorded the highest (79 per cent in 1800 ).

The fraction of the rural population engaged in agriculture in 1800 is required for the calculations in this article. The final column of Table I shows the values adopted in the later calculations. Generally, they equal the values shown in column 3. However, there is some danger in assuming that the mid- and late nineteenth century values were unchanged from 1800 . In the case of the Netherlands, for instance, the I 849 census indicates that 45 per cent of the male population was agricultural - nearly the same value as shown for Belgium (5I per cent) in I846. The implied fractions of the rural population engaged in agriculture were 77 per cent and 74 per cent for the countries, respectively, in the middle of the nineteenth century. The Dutch fraction had increased from 62 per cent c. 1800 . I have assumed the same evolution characterised Belgium and set its 1800 value equal to that of the Netherlands.

What is perhaps most surprising about the 1800 values shown in Table $I$ is the similarity of the figures across countries. While England had the lowest fraction ( $5 \mathrm{I}$ per cent) of its rural population engaged in agriculture, most of the continental countries had values in the 60's. Italy and Spain had higher values -74 per cent and 79 per cent, respectively - and they are countries which appear to have had less protoindustry than others. It might also be noted that the similarity in values across countries implies there is little correlation between the fraction of the rural population engaged in agriculture and the level of economic development.

The situation for earlier years is even more uncertain, for there were no censuses tallying occupations. Wrigley assumed that 80 per cent of the rural population was agricultural in England and France in 1500. While the figure, of course, is subject to error, there are two reasons for regarding it as approximately correct. First, it implies that the total population was about

${ }_{4}$ More exactly, Great Britain. 
Table I. Agricultural fraction of the rural population, nineteenth century.

\begin{tabular}{lllll}
\hline \hline Country & $\begin{array}{l}\text { Proportion } \\
\text { rural }\end{array}$ & $\begin{array}{l}\text { Proportion } \\
\text { agric. }\end{array}$ & $\begin{array}{l}\text { Proportion rural } \\
\text { agricultural }\end{array}$ & $\begin{array}{l}\text { Proportion rural } \\
\text { agricultural } \\
\text { in I800 }\end{array}$ \\
\hline Eng. \& Wales, I800 & $0.7 \mathrm{I}$ & 0.36 & $0.5 \mathrm{I}$ & $0.5 \mathrm{I}$ \\
Netherlands, I800 & 0.66 & $0.4 \mathrm{I}$ & 0.62 & 0.62 \\
Germany, I800 & $0.9 \mathrm{I}$ & 0.62 & 0.68 & 0.68 \\
France, I800 & $0.8 \mathrm{I}$ & 0.55 & 0.68 & 0.68 \\
Spain, I800 & 0.82 & 0.65 & 0.79 & 0.79 \\
Belgium, I850 & 0.66 & $0.5 \mathrm{I}$ & 0.77 & 0.62 \\
Austria, C. I850 & 0.87 & 0.54 & 0.62 & 0.62 \\
Italy, I850-70 & 0.78 & 0.58 & 0.74 & 0.74 \\
Poland, I897 & 0.82 & 0.46 & 0.59 & 0.59 \\
\hline \hline
\end{tabular}

Sources and definitions: Proportion rural - one minus the fraction urban. Urban population taken from Bairoch (1976, p. 312; 1988a, p. 259, except for England where it was estimated from Bairoch's reported urban populations in each Kingdom of the UK and for the following: Poland - Weber (1899, p. 106) indicates that Russian Poland was 21.8 per cent urban ( 78 per cent rural) in 1897 . Austria - Weber ( 1899, p. 95) indicates that Austria was 6.5 per cent urbanised but this figure must be doubled to allow for cities of 5,000I0,000 people. At the same time Hungary was 13.5 per cent urbanised (Weber I899, p. IOI).

Agricultural fraction of the population: Germany - De Vries and Van der Woude (1997, p. 528) citing Fischer et al. (1982). Spain - Simpson (I995, p. I8). France - Grantham (I99I, p. 34I). Italy - Kuznets (I97I, p. 25I) for I86I/7I. Poland - Mitchell (I978, p. 58). Austria - Mitchell (1978, p. 5I and 55) for Austria and Hungary in 1857. England \& Wales Deane \& Cole (1969, p. 142) Great Britain, I80I. Belgium - Kuznets (1971, p. 250) for 1846. Netherlands - De Vries and Van der Woude (1997, p. 524), c. I800.

The agricultural fraction of the rural population equals the agricultural fraction of the population or workforce divided by rural fraction of the population except for Belgium in I 800 where the Dutch value is used for reasons given in the text.

75 per cent agricultural once allowance is made for the urban population, and that was a typical value for a less developed country early in the twentieth century (Kuznets 1971). Second, a value of 80 per cent is consistent with the occupational structure in the rural Netherlands c. I800, once the rural manufacturers are removed. According to De Vries and Van der Woude (1997, p. 525), the population of the rural provinces was 60.5 per cent agricultural, 22.25 per cent industrial, and 17.25 per cent 'other' mainly trade and transport. ${ }^{5}$ The agricultural and industrial populations can

$s$ The figures are unweighted averages for the provinces North Holland, Friesland, Veluwe, and Overijssel labelled as 'rural (excluding industrial zones)', in De Vries and van der Woude (1997, p. 525). DeVries (1984, p. 240) assumes that the agricultural population was 80 per cent of the rural population in Europe as a whole in the early sixteenth century. 
be thought of as the export base of the rural economy with the remaining population providing services to the base. In that case, if the industrial population is removed, the 'other' population must be reduced by the fraction $60.5 /(60.5+22.25)$. Without the industrialists, the rural population would, then, have been 60.5 agricultural and 12.6 nonagricultural or 83 per cent agricultural. Perhaps reasoning along similar lines, De Vries and Van der Woude (I997, p. 233) assumed that 77 per cent of the rural Dutch population was agricultural in I510. Wrigley's value of 80 per cent is certainly near the mark.

Table 2 summarises estimates of the fraction of the rural population that was agricultural from 1300 to 1800 for the various European countries. The value was set at 0.8 in 1500 and earlier years for the reasons just discussed,

Table 2. Estimated population distribution, I300-1800 (millions).

\begin{tabular}{|c|c|c|c|c|}
\hline & Total & Urban & $\begin{array}{l}\text { Rural } \\
\text { nonagricultural }\end{array}$ & Agricultural \\
\hline \multicolumn{5}{|c|}{ England } \\
\hline 1300 & 5.0 & 0.22 & 0.96 & 3.82 \\
\hline 1400 & 2.5 & 0.20 & 0.46 & I. 84 \\
\hline 1500 & 2.5 & 0.18 & 0.46 & 1.85 \\
\hline 1600 & 4.4 & 0.43 & 0.96 & 3.03 \\
\hline 1700 & 5.2 & 0.88 & I.47 & 2.86 \\
\hline 1750 & 6.0 & I.39 & I.95 & 2.70 \\
\hline 1800 & 9.1 & $2.6 \mathrm{I}$ & 3.23 & 3.23 \\
\hline \multicolumn{5}{|c|}{ Austria/Hungary/Czechoslovakia } \\
\hline 1400 & 5.4 & 0.28 & 1.02 & 4.10 \\
\hline 1500 & 6.6 & 0.32 & I.26 & 5.02 \\
\hline 1600 & 8.0 & 0.39 & 1.98 & 5.63 \\
\hline 1700 & 9.2 & 0.44 & 2.80 & 5.96 \\
\hline 1750 & 10.7 & 0.78 & 3.37 & 6.55 \\
\hline 1800 & 14.0 & I.II & 4.90 & 7.99 \\
\hline \multicolumn{5}{|c|}{ Poland } \\
\hline 1400 & 2.75 & 0.12 & 0.53 & 2.10 \\
\hline 1500 & 4.0 & 0.24 & 0.75 & 3.01 \\
\hline 1600 & 5.0 & 0.38 & 1.25 & 3.37 \\
\hline 1700 & 6.0 & 0.26 & 1.95 & 3.79 \\
\hline 1750 & 7.0 & 0.31 & 2.54 & 4.15 \\
\hline 1800 & 9.0 & 0.43 & $3.5 \mathrm{I}$ & 5.06 \\
\hline \multicolumn{5}{|c|}{ Belgium } \\
\hline 1400 & I.O & 0.39 & 0.03 & 0.58 \\
\hline 1500 & 1.25 & 0.3 & 0.18 & 0.72 \\
\hline 1600 & 1.5 & 0.44 & 0.28 & 0.78 \\
\hline I 700 & I. 7 & 0.52 & 0.38 & 0.80 \\
\hline I750 & 2.3 & 0.51 & $0.6 \mathrm{I}$ & I.1 8 \\
\hline 1800 & 3.0 & 0.65 & 0.89 & I. 46 \\
\hline
\end{tabular}


Table 2. Continued.

\begin{tabular}{|c|c|c|c|c|}
\hline & Total & Urban & $\begin{array}{l}\text { Rural } \\
\text { nonagricultural }\end{array}$ & Agricultural \\
\hline \multicolumn{5}{|c|}{ Netherlands } \\
\hline 1500 & 0.95 & 0.28 & 0.13 & 0.54 \\
\hline 1600 & 1.5 & 0.52 & 0.25 & 0.73 \\
\hline I 700 & 1.9 & 0.74 & 0.37 & 0.79 \\
\hline 1750 & 1.9 & 0.69 & $0.4 \mathrm{I}$ & 0.80 \\
\hline I80o & 2.14 & 0.73 & 0.54 & 0.87 \\
\hline \multicolumn{5}{|c|}{ Germany } \\
\hline I400 & 7.0 & 0.78 & I.24 & 4.98 \\
\hline I500 & 10.5 & 0.86 & I.93 & 7.71 \\
\hline 1600 & 12.5 & 1.06 & 2.75 & 8.69 \\
\hline 1700 & 13.0 & 1.00 & 3.36 & 8.64 \\
\hline 1750 & 16.0 & I.4I & $4 \cdot 38$ & 10.22 \\
\hline I800 & 21.5 & 2.02 & 6.23 & 13.25 \\
\hline \multicolumn{5}{|l|}{ Spain } \\
\hline 1400 & 6.0 & I. 58 & 0.88 & $3 \cdot 54$ \\
\hline 1500 & $7 \cdot 5$ & I. 38 & $\mathrm{I} .22$ & 4.90 \\
\hline 1600 & 8.7 & 1.85 & I.37 & 5.48 \\
\hline 1700 & 8.6 & I. 75 & I. 44 & $5 \cdot 4 \mathrm{I}$ \\
\hline 1750 & 9.6 & 2.05 & I.59 & 5.96 \\
\hline 1800 & 13.0 & 2.54 & 2.20 & 8.26 \\
\hline \multicolumn{5}{|c|}{ France } \\
\hline I400 & I2.0 & I. 29 & 2.14 & 8.57 \\
\hline 1500 & 17.0 & I.49 & 3.10 & $12.4 \mathrm{I}$ \\
\hline 1600 & 19.0 & 2.05 & 4.07 & 12.88 \\
\hline 1700 & 22.0 & 2.72 & $5 \cdot 38$ & 13.90 \\
\hline 1750 & 24.5 & $3 \cdot$ II & 6.42 & I 4.97 \\
\hline 1800 & 28.3 & 3.65 & 7.89 & I6.76 \\
\hline \multicolumn{5}{|l|}{ Italy } \\
\hline 1300 & II.O & 2.29 & 1.74 & 6.97 \\
\hline 1400 & 8.0 & I.93 & $\mathrm{I} .2 \mathrm{I}$ & 4.87 \\
\hline I 500 & 10.0 & $2.2 \mathrm{I}$ & I. 56 & 6.23 \\
\hline 1600 & $13 \cdot 3$ & 3.00 & 2.27 & 8.03 \\
\hline 1700 & I3.4 & 3.03 & 2.49 & 7.88 \\
\hline 1750 & 15.5 & 3.49 & 2.88 & 9.13 \\
\hline 1800 & 18.5 & 4.06 & 3.75 & 10.69 \\
\hline
\end{tabular}

and the 1800 values in Table I were used for that date. Intervening values were interpolated, following Wrigley. ${ }^{6}$

6 There is one exception to this procedure. A value of 0.95 was used for Belgium in 1400 . Using a value of 0.8 implies an extremely high level of agricultural labour productivity. While that is possible, it seemed at least as likely that Belgium's exceptionally high urbanisation rate indicated that many activities usually done in the countryside were located in the cities. The implications of the alternative interpretation will be discussed later. 
Table 3. Relative increase in population by sector, I500-I750

$(1500=1.0)$.

\begin{tabular}{lllll}
\hline \hline & Total & Urban & $\begin{array}{l}\text { Rural } \\
\text { nonagricultural }\end{array}$ & Agricultural \\
\hline England & 2.4 & 7.7 & 4.24 & $\mathrm{I} .46$ \\
Netherlands & 2.0 & 2.46 & 3.07 & $\mathrm{I} .48$ \\
Belgium & $\mathrm{I} .84$ & $\mathrm{I} .46$ & $3.8 \mathrm{I}$ & $\mathrm{I} .64$ \\
Germany & $\mathrm{I} .52$ & $\mathrm{I} .63$ & 2.27 & $\mathrm{I} .33$ \\
France & $\mathrm{I} .44$ & 2.09 & 2.07 & $\mathrm{I} .2 \mathrm{I}$ \\
Austria/Hungary & $\mathrm{I} .62$ & 2.40 & 2.67 & $\mathrm{I} .30$ \\
Poland & $\mathrm{I} .75$ & $\mathrm{I} .29$ & 3.38 & $\mathrm{I} .38$ \\
Italy & $\mathrm{I} .55$ & $\mathrm{I} .58$ & $\mathrm{I} .85$ & $\mathrm{I} .47$ \\
Spain & $\mathrm{I} .28$ & $\mathrm{I} .49$ & $\mathrm{I} .30$ & $\mathrm{I} .22$ \\
\hline \hline
\end{tabular}

Source: Table 2.

Table 3 summarises the population breakdowns implied by these assumptions. The figures indicate that successful and unsuccessful economies evolved in different ways. I concentrate on the period I500-I750, which witnessed the great divergence in European incomes (Allen 1998). With real wages as the standard, 7 England was the most successful economy in this period, followed by the Belgian and the Dutch. In the English case, the real wage rose, while in the Belgian and Dutch it declined only slowly. In the rest of Europe, real wages dropped by half or more.

Some differences between successful and unsuccessful economies are apparent in the growth of the population and its distribution.

- The total population grew in all countries, but growth was most rapid in England, Belgium, and the Netherlands. The growth or only modest declines in their wages is particularly remarkable in light of their high population growth rates.

- Population increased in all three sectors of the economy. There was remarkably little difference in the rate of growth of the agricultural population, which increased between one third and two thirds in most countries. Most surprisingly, the growth was largest in the most successful economies. They did not grow by reducing the agricultural work forces or by holding down the growth rate in comparison to other countries.

- The rural nonagricultural sector increased in all economies, but at different rates. Growth was least in Spain - only a 30 per cent increase between 1500 and 1750 - and most in England where the rural nonagricultural population increased by a factor of 4.24. Belgium and the Netherlands also had substantial proportional increases, but

\footnotetext{
7 North and Thomas (1973, p. II7-18) argue in this way using wages.
} 
Table 4. Distribution of the population by sector, 1500.

\begin{tabular}{llll}
\hline \hline & Urban & $\begin{array}{l}\text { Rural } \\
\text { nonagriculture }\end{array}$ & Agriculture \\
\hline England & 0.07 & 0.18 & 0.74 \\
Netherlands & 0.30 & 0.14 & 0.56 \\
Belgium & 0.28 & 0.14 & 0.58 \\
Germany & 0.08 & 0.18 & 0.73 \\
France & 0.09 & 0.18 & 0.73 \\
Austria/Hungary & 0.05 & 0.19 & 0.76 \\
Poland & 0.06 & 0.19 & 0.75 \\
Italy & 0.22 & 0.16 & 0.62 \\
Spain & 0.19 & 0.16 & 0.65 \\
\hline \hline
\end{tabular}

Source: Table 2.

so did Poland. Growth in the rural nonagricultural population was less but not insignificant in Germany, France, and Italy.

- The urban population increased between 50 per cent and Ioo per cent in most of Europe between 1500 and 1750. Larger increases were achieved in Austria/Hungary and in the Netherlands. The English urban population increased by a factor of almost eight, which was dramatically above any other economy's.

These differences in growth translated into differences in economic structure. Table 4 and 5 show the distribution of the population across the three sectors in 1500 and 1750 .

In 1500 about three fourths of the work force was employed in agriculture in most countries in Europe. This figure, as noted previously, was typical of

Table 5. Distribution of the population by sector, I750.

\begin{tabular}{llll}
\hline \hline & Urban & $\begin{array}{l}\text { Rural } \\
\text { nonagriculture }\end{array}$ & Agriculture \\
\hline England & 0.23 & 0.32 & 0.45 \\
Netherlands & 0.36 & 0.22 & 0.42 \\
Belgium & 0.22 & 0.26 & $0.5 \mathrm{I}$ \\
Germany & 0.09 & 0.27 & 0.64 \\
France & 0.13 & 0.26 & $0.6 \mathrm{I}$ \\
Austria/Hungary & 0.07 & 0.32 & $0.6 \mathrm{I}$ \\
Poland & 0.04 & 0.36 & 0.59 \\
Italy & 0.23 & 0.19 & 0.59 \\
Spain & 0.21 & 0.16 & 0.63 \\
\hline \hline
\end{tabular}

Source: Table 2. 
a less developed country in the early twentieth century. By this measure, most of Europe was at a similar level of development in 1500.

Some countries, however, had developed past this point. The most important examples were the Netherlands, Belgium, and Italy where the agricultural proportions were 56 per cent, 58 per cent, and 62 per cent, respectively. Spain at 69 per cent also appears slightly less agricultural than the norm but not as advanced as the other three. The corresponding increase in the nonagricultural populations was all in the cities: the Netherlands, Belgium, Italy, and Spain all had higher urbanisation rates than the other countries. There was not much difference between the countries in terms of the fraction of the population in the rural nonagricultural category and no obvious relationship between that variable and the degree of development.

The situation changed markedly between 1500 and 1750 . The share of the population in agriculture fell everywhere but by very different amounts.

- Progress was most dramatic in England where the share of the population in agriculture declined from 74 per cent to 45 per cent. That drop was matched by large increases in both the urban and rural nonagricultural fractions of the population.

- The Dutch economy also showed progress in the period. It had been one of the most advanced economies in 1500, so the changes in the proportions were less than in England, but the structure achieved in 1750 was, if anything, more modern. The fraction employed in agriculture ( 42 per cent) was slightly less than in England. There had been increases in the proportions of the population employed in both the rural nonagricultural and urban sectors. The urbanisation rate in $\mathbf{1} 750$ was higher than the English.

- The Belgian economy also showed progress from an advanced position. The fraction employed in agriculture dropped from 58 per cent to 5I per cent. The fraction employed in cities declined, however, so all of the extra nonagricultural employment occurred in the countryside.

The remaining countries in Europe were unsuccessful economies between 1500 and 1750 in the sense that their real wages fell sharply. There were two patterns in unsuccessful economies.

- In Germany, France, Austria/Hungary, and Poland, the fraction employed in agriculture dropped from about three quarters to about 60 per cent. Little, if any, of this decline was accounted for by increased urbanisation; indeed, the fraction of the population living in cities rose only slightly. All of the extra nonagricultural employment occurred in the countryside. While rural industry may have been an engine of growth in England or the 
Netherlands, it was quite likely a response to falling wages on most of the continent.

- Progress was least in Spain and Italy where the decline in the proportion of the population in agriculture was inconsequential. Indeed, the economic structures of these countries show very little change between 1500 and 1750 .

\section{Agricultural output}

Agricultural output is the numerator in output per worker. Here we depart from Wrigley by relaxing the assumption that consumption per head is a constant. Instead, it is made a function of wages and prices:

$$
c=\operatorname{ap}^{\mathrm{e}} \mathrm{ig}^{\mathrm{g}} \mathrm{b}
$$

where $c$ is per capita consumption, $p$ is the nominal price of agricultural production, $i$ is nominal income per head, and $m$ is the nominal price of other consumer goods, and $a$ is an arbitrary constant. The own price, income, and cross price elasticities of demand are $e, g$, and $b$. Consistency with consumer theory requires that they sum to zero. Consequently, $p$, $i$ and $m$ can all be expressed in 'real' terms by dividing them by a consumer price index, $\mathrm{C}$.

$$
\mathrm{Q}=\mathrm{rcN}=\mathrm{raP}^{\mathrm{e}} I^{\mathrm{g}} \mathrm{M}^{\mathrm{b}} \mathrm{N}
$$

where $Q$ is agricultural output, $P=p / C$ is the real price of agricultural products, $I=i / C$ is real income per head, and $M=m / C$ is the real price of other consumer goods, $\mathrm{N}$ is the population, and $r$ is the ratio of total agricultural production to total agricultural consumption. In other words, $r$ is the adjustment for international trade that relates domestic consumption to domestic production.

Calculation of agricultural output requires all of the elasticities as well as time series of all of the variables on the right side of equation (3). P, I, and $M$ are derived from the wage and price series described in Allen (1998). All prices and wages are converted to grams of silver. $I$ is the daily wage of craftsmen and C is the consumer price index derived in Allen (1998). P and $M$, the prices of agricultural and nonagricultural goods are computed from the components of $\mathrm{C}$; in particular, $\mathrm{P}$ includes the prices of bread, beans or peas, meat, butter or olive oil, cheese, eggs, and beer or wine, while $M$ includes the prices of soap, linen cloth, candles, lamp oil and fuel. ${ }^{8} \mathrm{P}, \mathrm{I}$, and $M$ are all normalised by dividing them by the corresponding English values in 1500 , and the constant $a$ is given a value of one. Hence, agricultural output for all countries is measured relative to the English level in I500.

The parameter values are chosen to reflect early modern demand pat-

\footnotetext{
${ }^{8}$ A Laspeyres index is computed for $\mathrm{P}$ and $\mathrm{M}$, in which the baskets of goods used as weights are the same as those used in $\mathrm{C}$ and given in Allen (1998, Table 3).
} 
terns, a subject which has been discussed considerably in the case of England, most recently by Clark et al. (1995, pp. 221-5). Modern budget studies for developing countries suggest that $b$ is a small, positive number, that is usually taken to be 0.1 . The own price elasticity $e$ was about -0.6 , and the income elasticity $g$ must have been 0.5 to satisfy the condition that the coefficients sum to zero. I report results for these values. Simulations with other values produce very similar outcomes.

The final parameter is $r$, the ratio of domestic production to consumption. Multiplication by $r$ in equation (3) converts what is otherwise an estimate of the growth of consumption into an estimate of production. In closed economies, $r$ equals one, and that is the value adopted here for most cases. This assumption can be tested against the experience of the Netherlands and England, which were arguably the two economies where trade was most important. De Vries and van der Woude (I997, p. 233) estimate that $r$ was 0.9 in the Netherlands in I5I0, 0.95 in I650, and I.I in I8IO. The Netherlands were famous in the sixteenth and seventeenth centuries as the destination of Baltic grain exports, and they are usually presumed to have played an important role in feeding the Low Countries. However, this trade only accounted for Io per cent of agricultural consumption. By I8ro, the situation had reversed, and the Dutch become food exporters, but again the deviation of production from consumption was only ro per cent.

Trade was less important in the case of England. There is no indication that $r$ differed from one before the middle of the seventeenth century. Then England began exporting significant quantities of grain, so $r$ rose in the middle of the eighteenth century, when it began to decline. By 1800 , it had dropped to 0.9. Thereafter imports bulked ever larger as a source of English food, but that rise occurred after the period analysed here (Wrigley I985, Overton 1996b, Clark et al. 1995).

In the cases of England and the Netherlands, I have used values of $r$ that trace the history summarised here. The combined net imports of these countries were treated as a net export of Poland to balance trade within Europe. The implied net trade balance of Poland is always less than ten per cent of its production, so this procedure has little impact on the estimates of Polish production. For other countries, I have used a value of one.

Before considering the full range of estimates, it is useful to check the English, Dutch, and French estimates against those presented in other studies. These comparisons provide some confidence in the figures offered here.

I begin with England. The approach adopted here differs in several ways from the conventional methodology in measuring output growth in English agriculture. The most important difference is in the price indices. In the previous studies of English production, indices of the wholesale prices of agricultural and industrial goods were used, while indices of retail food and nonfood prices are used in this study. The alternatives reflect two ways in which the agricultural terms of trade are conventionally measured. They 


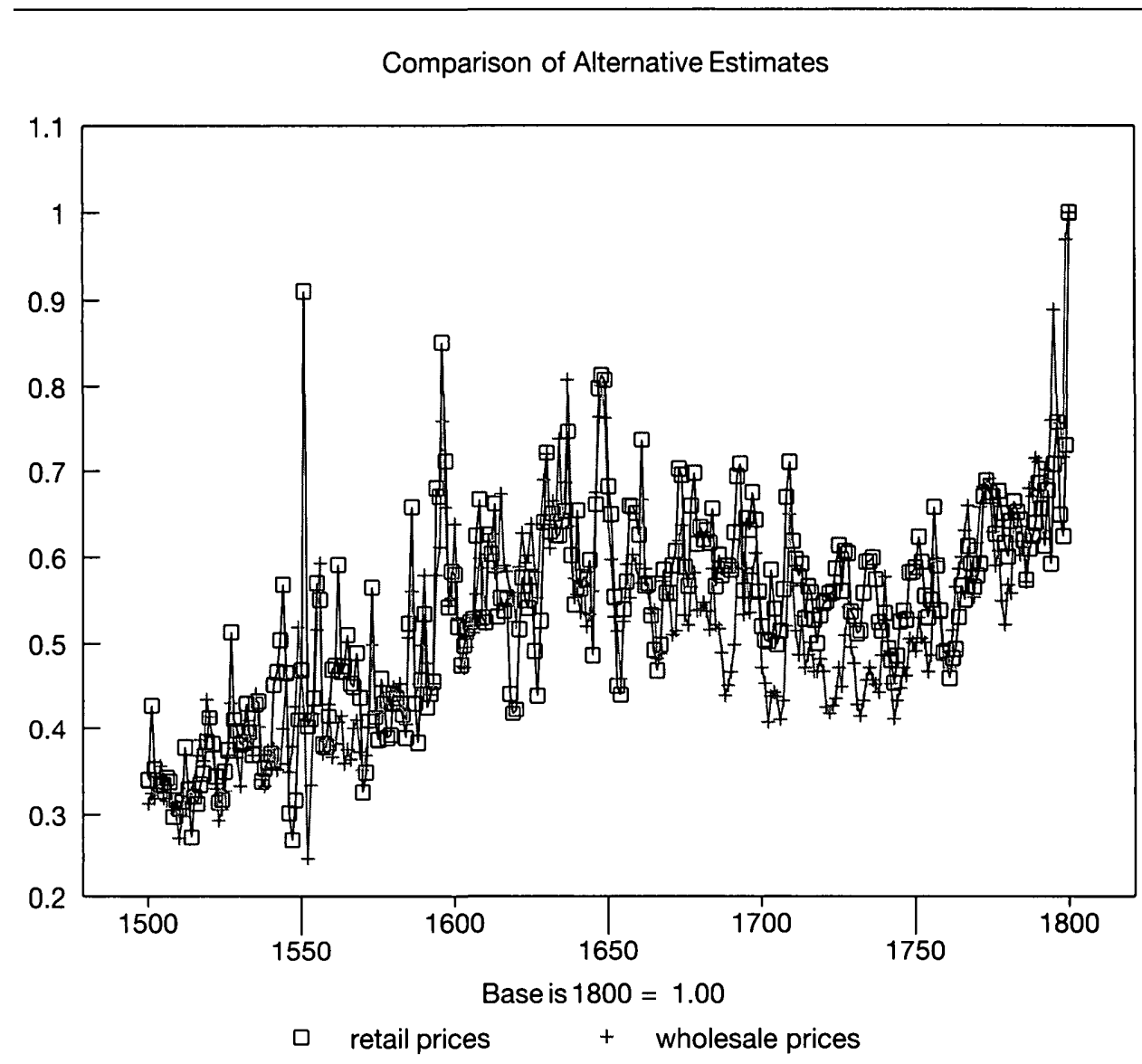

Figure I. English agricultural terms of trade $(I 800=I)$.

differed very little for early modern England (Figure I). The index calculated here also differs from others in using a newly computed consumer price index, and relying on the craftsman's wage rate to measure income per head rather than a more broadly based index of earnings.

To see whether these changes lead to any differences in the estimate of agricultural output, I have computed an annual output index using the methodology of this study, which can be compared to an index using more conventional price and income indices and presented in Allen (1999). The two indices are graphed in Figure 2. There is clearly little difference in output growth, which suggests that the differences in procedure have little practical import.

De Vries and van der Woude (1997, p. 233) give estimates of the growth of agricultural output in the Netherlands that can also be compared with the estimates presented here. Their approach does not rely on a demand curve. Instead, they estimate per capita food consumption in I5IO and I8IO from limited information about diet (De Vries and Van der Woude 1997, pp. 232, 622-7). Changes in the relative production of industrial crops are also estimated. Allowing for international trade, this procedure implies that agri 
Comparison of Alternative Estimates

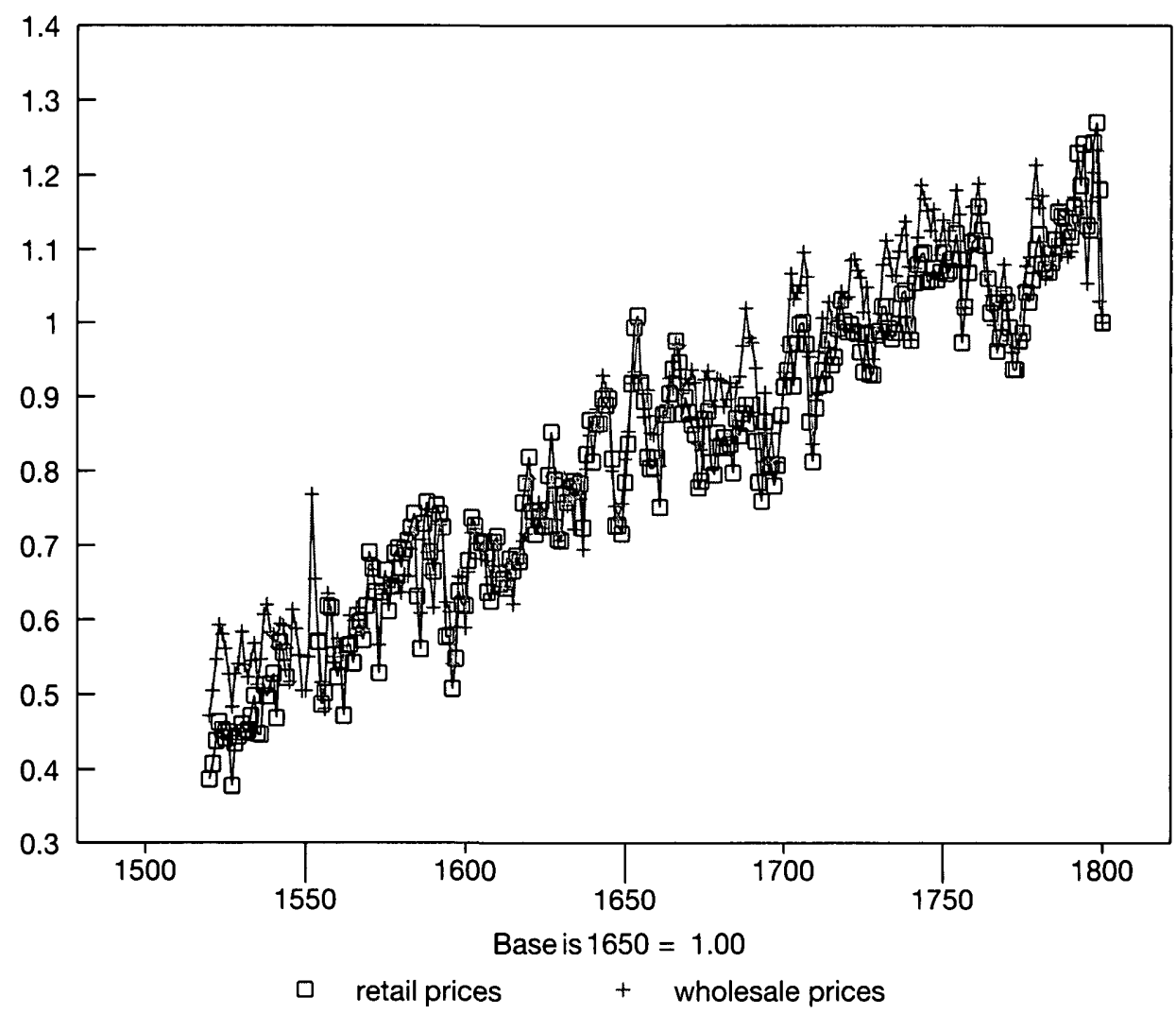

Figure 2. English agricultural output, I520-I800 $(1650=I)$.

cultural production increased threefold from I5IO to I8IO with most of the growth coming before 1700 . Per capita consumption increased $4 \mathrm{I}$ per cent over the three centuries. Another estimate based on rent data and not reported in detail implies that growth may have only increased by 2.6 times, or by 19 per cent per capita.

The estimates developed here point to somewhat less growth than estimated by De Vries and van der Woude. From I500 to I800, equation (3) implies that output increased by a factor of 2.19 , per capita consumption dropped, and per capita production remained unchanged once allowance is made for the Netherlands' shift from importing to exporting food. The main reason for the difference in growth is that my figures rely on a real wage series that declined from 1500 to I800 - a pattern broadly consistent with De Vries' and Van der Woude's (I997, p. 629) findings. The falling real wage implies, by equation (3), that per capita consumption declined. De Vries and van der Woude, in contrast, posit a 15 per cent increase in consumption per head even though incomes were falling. Estimating output growth from equation (3) precludes that conclusion. 


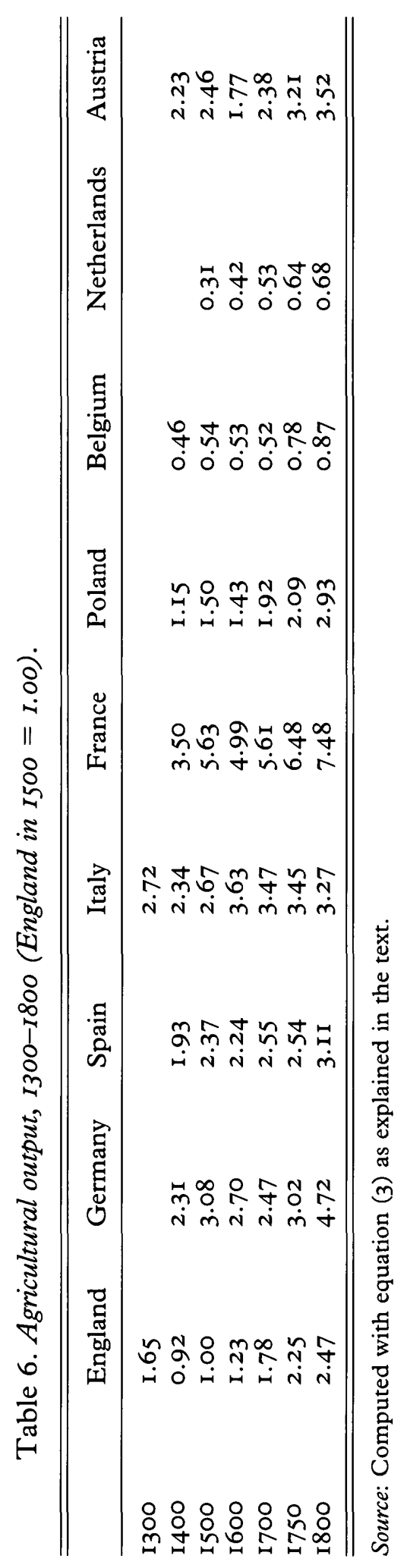


The estimates presented here for France are similar to those developed by Hoffman (1996, p. I35). He computed the growth in output as the growth in inputs plus the growth in productivity. Between 1500 and 1800 , his figures imply that output increased between -3 per cent and +93 per cent. The average of these extremes is 45 per cent, while my estimate of output growth over the same period is 33 per cent. For the eighteenth century, Hoffman's figures imply that output increased between I 6 per cent and 39 per cent, while my calculations again suggest a 33 per cent rise. The methods give similar results.

Table 6 summarises the volume of agricultural output for the principal European countries implied by equation (3). The significance of these figures is sometimes clearer by putting them on a per capita basis, as in Table 7:

- In England and Italy, the series begin in 1300 and, therefore, show the impact of the Black Death. Italian production fell by 14 per cent between 1300 and I400, while English production declined 44 per cent. Per capita production rose 12 per cent in England and I6 per cent in Italy.

- Between 1500 and 1800 , production increased in all countries. The rise was greatest (on a percentage basis) in the Netherlands and England. In both countries, the gains were minimal after I750. These findings are consistent with those of De Vries and van der Woude (1997, pp. 232-3) regarding the Netherlands and with the view of most recent commentators on England who have emphasised that the seventeenth and early eighteenth centuries were the key years for output and yield increases, while the parliamentary enclosures were remarkable for their lack of progress in those regards (Allen 1992, 1999, Clark 1998).

- On most of the continent, output increases were less substantial and failed to keep pace with population growth. Only in England (through to 1750) and in the Netherlands did the output increase keep pace with population growth. This achievement is all the more remarkable given that the population grew faster in England and the Netherlands than in other parts of Europe.

\section{Agricultural labour productivity}

Dividing the index of agricultural output by the agricultural population gives an index of agricultural labour productivity. These productivity series are shown in Table 8, and the values for England, Italy, France, Spain, Belgium, and the Netherlands are plotted in Figure 3. The Figure highlights the major patterns in productivity change in European agriculture from the Middle Ages to the industrial revolution. It is useful to distinguish three groups: the successful, the moderately successful, and the unsuccessful.

The unsuccessful group was the largest. Italy is the paradigm case. The 


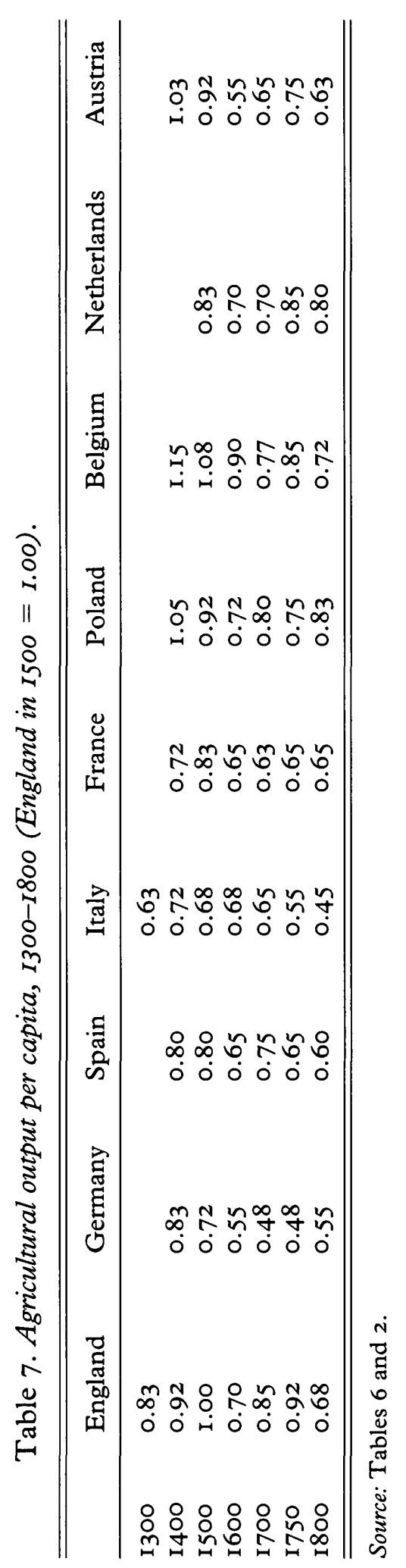




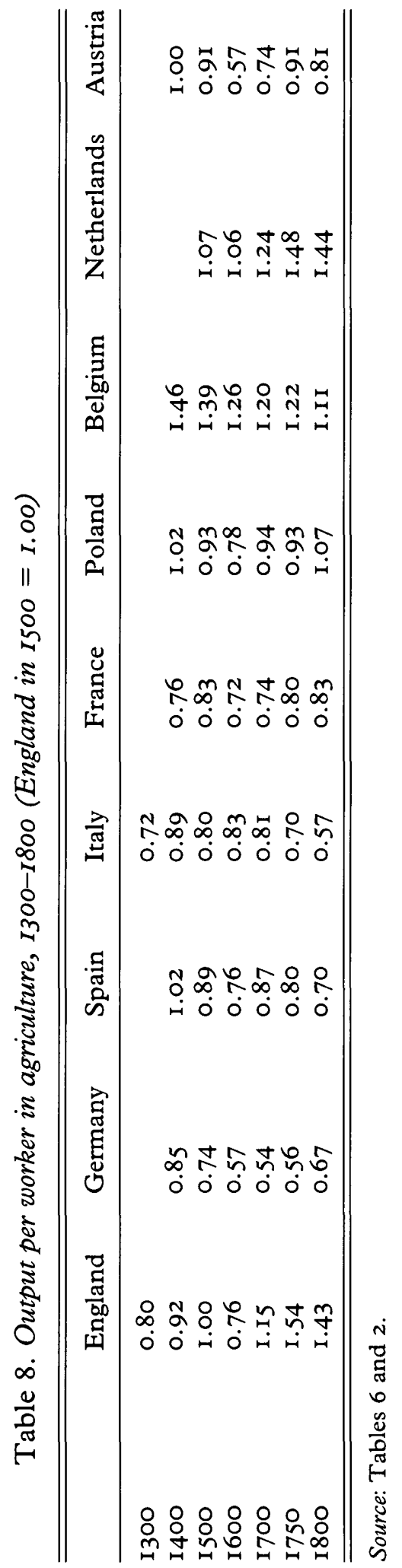




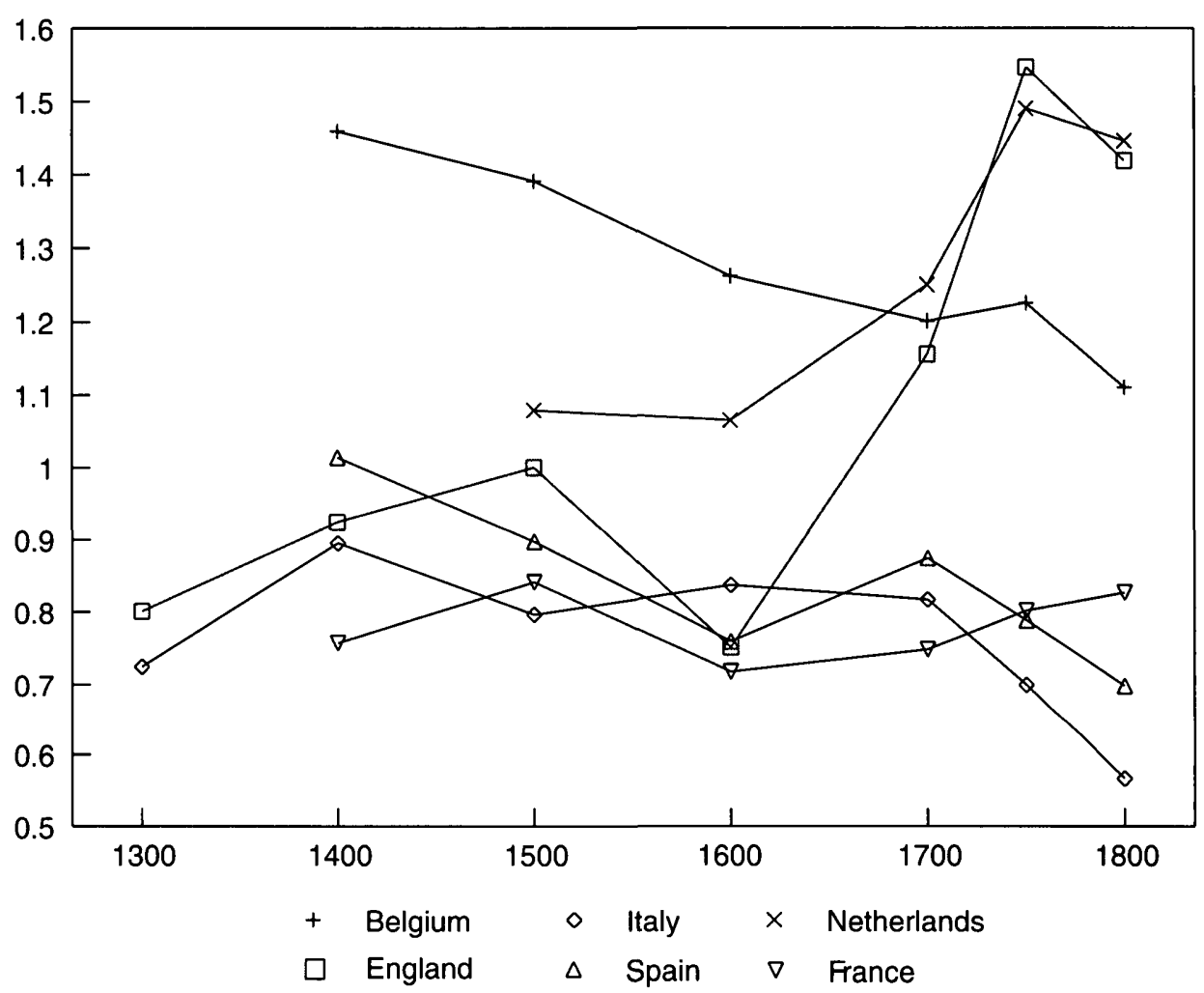

Figure 3. Output per worker in agriculture, 1300-1800 (England in $1500=1.00)$.

Italian series begins in 1300 . The Black Death increased output per worker, as one would expect. Productivity then declined until I800 at which time it had dropped below its 1300 level. Population growth and diminishing returns to labour account for the productivity decline. The productivity histories of Spain, Germany, and Austria were essentially indistinguishable. These countries missed an agricultural revolution.

The histories of France and Poland support a slightly more optimistic assessment, but their performance was still far below that of the successful countries.

Output per worker in France was similar to that in most continental countries during the early modern period. Thereafter, there was a modest rise until 1800 . While the increase was not nearly as pronounced as in England or the Netherlands, it is significant since it occurred in spite of a rise in population. Hoffman (1996, pp. 8I-142) has argued that French productivity performance varied widely between regions with high levels, like those in England, achieved in the Paris Basin. The estimates presented here are consistent with such a nuanced interpretation.

The Polish figures are undoubtedly the least reliable. Agricultural labour 
productivity was generally fairly high in Poland and may have risen further in the late eighteenth century. Poland is well known for the imposition of a severe form of serfdom in the sixteenth and seventeenth centuries, and that serfdom is often explained in terms of the high land-labour ratio (Domar 1970). That high ratio may also explain the high level of labour productivity. While servile agriculture has often been regarded as technologically inefficient, that interpretation has been disputed by some historians of American slavery (Fogel and Engerman 1974). Perhaps Polish agriculture is another example of a coercive - yet productive - agriculture.

The moderately successful country was Belgium. It had the highest level of labour productivity in the late medieval period, and, indeed, the agriculture of Flanders was highly renowned. ${ }^{9}$ Output per worker declined slowly thereafter as the population expanded, but Belgian agriculture still achieved a high standard of performance.

The Netherlands and England had the two most successful agricultures. In I500 output per worker in the Netherlands was not any higher than in most countries, but it rose rapidly reaching Belgian levels of efficiency c. I700. Thereafter, there was little difference in labour productivity in Belgium and the Netherlands. The success of Dutch agriculture in the Golden Age is clearly shown in Figure 3.

English agriculture was equally successful in the early modern period. From 1300 to 1600 , the English productivity record was similar to that of the unsuccessful countries. From I300 to I500, output per worker rose dramatically in response to the Black Death and the continuing demographic crisis. In the next century, population growth resumed, and output per worker dropped. After 1600 , the typical pattern of a nondeveloper was broken, and the curve of output per worker rose steeply and surpassed all other countries by 1750 . There was a slight drop in English productivity between 1750 and I800, so England and the Netherlands ended the eighteenth century in a tie for the most productive agriculture, according to these figures.

These conclusions about labour productivity are broadly consistent with the literature on European agricultural history, but they do differ from some previous calculations in significant ways. Wrigley's estimates are a case in point. His figures show English and French productivity to have been similar c. 1500. Over the next three centuries, output per worker then rose 88 per cent in England and 23 per cent in France according to Wrigley. My estimates indicate lower rates of productivity growth in both countries and always show English productivity to have been higher. The reason for these differences is that consumption per head was not a.constant, as assumed by Wrigley.

\footnotetext{
9 As noted earlier, the I400 value would have been even higher had the usual assumption been made that 80 per cent of the rural population was agricultural.
} 


\section{Conclusion}

This article has been an exercise in historical reconstruction based on simple economic theory. One can always debate whether a single, unchanging demand curve describes agricultural consumption across Europe for hundreds of years. Likewise, it is debatable whether the population can be split cleanly into the three groups distinguished here. And, of course, the data underlying all of the reconstructions are subject to significant margins of error. In view of these caveats, it is all the more remarkable that some simple patterns are clearly discernible.

First, there were two groups of successful economies at the end of the medieval period. The largest bordered the Mediterranean - Italy and Spain - while the smallest faced the North Sea - Belgium and the Netherlands (although there was little activity in the latter before 1500). Agricultural labour productivity was higher in Belgium than in the other three. After I500, their paths diverged. Output per worker declined in Italy and Spain, there was no structural change, and real wages fell. Output per worker remained high in Belgian agriculture and rose to that level in the Netherlands. The fraction of the workforce engaged in agriculture declined in both countries. Rural industry and the urban economies expanded (although in Belgium the urban population did not grow as fast as the total population). Wages declined only slightly over the period. By I750, Italy and Spain had become underdeveloped parts of Europe, while Belgium and the Netherlands were advanced economies.

The remaining European countries were uniformly backward in 1500 . Three quarters of the population were agricultural. Labour productivity in agriculture was low compared to Belgium and on a par with that in Spain and Italy. The urban populations were very small. Change occurred in all of these countries, but, again, there were two paths of development.

England was the great success story. Output per worker in agriculture traced out a population-induced rise and fall like Italy's from I300 to I600. In the next century, the pattern was broken. Productivity shot up instead of continuing its decline. By I750, output per worker in English agriculture had reached the Belgian and Dutch levels. At the same time, the nonagricultural economy grew explosively. Both the urban and the rural nonagricultural populations grew more rapidly in England than anywhere else in Europe. By 1750 , the share of the workforce in agriculture had dropped to 45 per cent - only three percentage points above the Dutch level. While there were ups and downs, the trend of real wages was rising throughout the period.

Structural change occurred in the rest of the backward economies c. I500, but the pace was much slower. Output per worker in agriculture usually declined although there were weak signs of advance in France and in Poland in the early eighteenth century. The share of the workforce in 
agriculture dropped to about 60 per cent. There was little growth in the fraction of the population living in cities. Most of the increase in nonagricultural employment was in the countryside. In these countries, rural industrialisation should be thought of as a response to overpopulation and limited opportunities in agriculture rather than as a growth pole of the economy.

This review of the evidence shows that no single factor was perfectly correlated with economic success in early modern Europe. Nevertheless, some regularities stand out. The first is the performance of agriculture: all of the successful economies in I800 had high levels of agricultural labour productivity. The second factor is urbanisation: high levels of urbanisation were generally associated with success, although some less successful economies also had significant fractions of the population living in cities. The final factor to consider is notable for its irrelevance. While much has been claimed for rural industry as an engine of growth, it appears to have been at least as common in unsuccessful economies as it was in successful ones. Success depended on a productive agriculture and a vigorous urban economy rather than on a large protoindustrial sector.

\section{References}

Allen, R. C. (1992). Enclosure and the Yeoman: The Agricultural Development of the South Midlands, I450-1850. Oxford: Clarendon Press.

ALLEN, R. C. (1998). The great divergence: wages and prices in Europe from the Middle Ages to the First World War. UBC Department of Economics Discussion Paper 98-I2.

AlleN, R. C. (1999). Tracking the Agricultural Revolution. Economic History Review, 2nd series, 52, pp. 209-35.

AlleN, R. C. and Ó GRÁDA, C. (1988). On the road again with Arthur Young: English, Irish, and French agriculture during the Industrial Revolution. Fournal of Economic History 38, pp. 93-II6.

BAIROCH, P. (1965). Niveau de développement économique de I8Io à I9IO. Annales: économies, sociétés, civilisations 20, pp. I09I-17.

BaIroch, P. (1976). Population urbaine et taille des villes en Europe de I600 à 1970. Revue d'Histoire Économique et Sociale 54, pp. 304-35.

Bairoch, P. (1988a). La Population des Villes Européenes: Banques de Données et Analyse Sommaire des Résultats. Genève: Librairie Droz.

Bairoch, P. (1988b). Cities and Economic Development, trans. C. Braider. Chicago: University of Chicago Press.

CHORLEY, P. (I98I). The agricultural revolution in northern Europe, I750-1880: nitrogen, legumes, and crop productivity. Economic History Review, 2nd series, 34, pp. 71-93.

CLARK, G. (1987). Productivity growth without technical change in European agriculture before 1850. Fournal of Economic History 47, pp. 419-32. 
ClaRK, G. (1989). Productivity growth without technical change in European agriculture: reply to Komlos. Fournal of Economic History 49, pp. 979-9I.

Clark, G. (I99I). Labour Productivity in English Agriculture, I300-I860. In B. M. S. Campbell and M. Overton (eds), Land, Labour, and Livestock: Historical Studies in European Agricultural Productivity. Manchester: Manchester University Press.

ClaRK, G. (I998). Commons sense: common property rights, efficiency, and institutional change. Fournal of Economic History 58, pp. 73-IO2.

Clark, G., Huberman, M. and Lindert, P. H. (I995). A British Food Puzzle, I770-1850. Economic History Review, 2nd series, 48, pp. 215-37.

CRAFTS, N. F. R. (1976). English economic growth in the eighteenth century: a re-examination of Deane and Cole's estimates. Economic History Review, and series, 29, pp. 226-35.

DeANe, P., and Cole, W. A. (I969). British Economic Growth: 1689-1959, 2nd edn. Cambridge: Cambridge University Press.

DE VRIES, J. (1984). European Urbanization, 1500-1800. Cambridge, MA: Harvard University Press.

De Vries, J. and VAn Der Woude, A. M. (1997). The First Modern Economy: Success, Failure, and Perseverance of the Dutch Economy, 1500-1815. Cambridge: Cambridge University Press.

DOMAR, E. (1970). The causes of slavery or serfdom: a hypothesis. fournal of Economic History 30, pp. 18-32.

FISCHER, W., KRENGEL, J. and WIETOG, J. (1982). Sozialge schichtliches Arbeitsbuch. Band I. Materialen zur Statistik des Deutchen Bundes, I8I5-I870. Munich: C. H. Beck.

Fogel, R. W., and ENGERMAN, S. L. (1974). Time on the Cross: The Economics of American Negro Slavery. Boston, MA: Little, Brown.

GRANTHAM, G. (I99I). The growth of labour productivity in the production of wheat in the Cinq Grosses Fermes of France, 1750-1929. In B. M. S. Campbell and M. Overton (eds), Land, Labour, and Livestock: Historical Studies in European Agricultural Productivity. Manchester: Manchester University Press.

Hoffman, P. T. (1996). Growth in a Traditional Society: The French Countryside, 1450-1815. Princeton, NJ: Princeton University Press.

JACKSON, R. V. (1985). Growth and deceleration in English agriculture, I660-I790. Economic History Review, 2nd series, 38, pp. 333-5I.

KomLOS, J. (1988). Agricultural productivity in America and eastern Europe: a comment. Fournal of Economic History 48, pp. 655-64.

KuZNETS, S. S. (I97I). Economic Growth of Nations. Cambridge, MA: Harvard University Press.

MrTCHELl, B. R. (1978). European Historical Statistics, 1750-1970, abridged edn. London: Macmillan.

North, D. C. and Thomas, R. P. (1973). The Rise of the Western World: A New Economic History. Cambridge: Cambridge University Press.

O'BRIEN, P. K. and KeYDER, C. (1978). Economic Growth in Britain and France, 1780-I9I4: Two Paths to the Twentieth Century. London: George Allen and Unwin.

Overton, M. (1996a). Re-establishing the agricultural revolution. Agricultural History Review 44, part I, pp. I-20. 
Overton, M. (1996b). Agricultural Revolution in England. Cambridge: Cambridge University Press.

Persson, K. G. (1988). Pre-Industrial Economic Growth: Social Organization and Technological Progress in Europe. Oxford: Basil Blackwell.

Persson, K. G. (I99I). Labour productivity in medieval agriculture: Tuscany and the Low Countries. In B. M. S. Campbell and M. Overton (eds), Land, Labour, and Livestock: Historical Studies in European Agricultural Productivity. Manchester: Manchester University Press.

PERSSON, K. G. (1993). Was there a productivity gap between fourteenth-century Italy and England? Economic History Review, 2nd series, 46, pp. I05-I4.

Simpson, J. (1995). Spanish Agriculture: The Long Siesta, 1765-1965. Cambridge: Cambridge University Press.

Slicher van Bath, B. H. (1963). Yield Ratios, 810-1820, A.A.G. Bijdrag en, 10.

Van Bavel, B. J. P. and Thoen, E. (eds) (n.d.). Land Productivity and Agro Systems in the North Sea area: Elements for a Comparative History, forthcoming. Weber, A. F. (1965 [1899]). The Growth of Cities in the Nineteenth Century: $A$ Study in Statistics. Ithaca, NY: Cornell University Press, 2nd printing.

WRIGLEY, E. A. (1985). Urban gowth and agricultural change: England and the Continent in the early modern period. fournal of Interdisciplinary History 15, pp. 683-728. 